IRA-International Journal of Education \& Multidisciplinary Studies

ISSN 2455-2526; Vol.06, Issue 03 (2017)

Pg. no. 266-274

Institute of Research Advances

https://research-advances.org/index.php/IJEMS

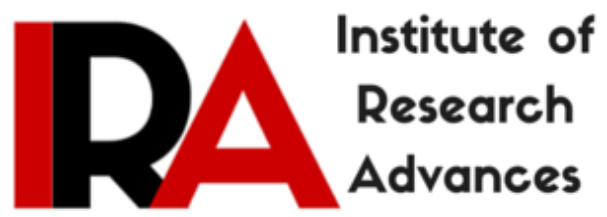

\title{
Motive Factors of B.Ed Student Teachers for Choosing Teaching as their Calling
}

\section{Dr. K. Sheeba}

Associate Professor of Biological Science, School of Education, Vels University, Pallavaram, Chennai - 117, India.

Type of Review: Peer Reviewed.

DOI: http://dx.doi.org/10.21013/jems.v6.n3.p7

\section{How to cite this paper:}

Sheeba, K. (2017). Motive Factors of B.Ed Student Teachers for Choosing Teaching as their Calling. IRA International Journal of Education and Multidisciplinary Studies (ISSN 2455-2526), 6(3), 266-274. doi:http://dx.doi.org/10.21013/jems.v6.n3.p7

(C) Institute of Research Advances

\section{(c) Br-No}

This work is licensed under a Creative Commons Attribution-Non Commercial 4.0 International License subject to proper citation to the publication source of the work.

Disclaimer: The scholarly papers as reviewed and published by the Institute of Research Advances (IRA) are the views and opinions of their respective authors and are not the views or opinions of the IRA. The IRA disclaims of any harm or loss caused due to the published content to any party. 


\begin{abstract}
It is obvious that quality of teaching force is not governed only by the qualification, pedagogical knowledge and teaching skill of teachers, but also their enthusiasm, motivation, dedication and commitment in teaching. Student teachers have a substantial impact on the education of future generations. In order for a system of teacher education to be effective, it needs to recognize and build on the characteristics and motivations that student teachers bring with them when they enter teacher education program after their completion of graduation or post graduation. Holistic teacher building is necessary and therefore teacher education needed more emphasis than mere training by high positive motivation of the student teachers for choosing the teaching as their calling. The data for the present study were collected from a population of student teachers. In the present study, Survey Method is employed to describe and interpret. The sample size chosen for B.Ed., student teachers are 500 (250 Male and 250 Female) of the Pudukkottai District, Tamil Nadu, India. The findings revealed that female student teachers have manifested significantly higher level in all the selected variables when compared to their counter parts. The independent variables such as positive and negative emotion, altruism, moral value, teacher's attitude and personal and social influence correlate significantly with motivation positively. The coefficient of determination $R$ square measures the goodness-of-fit with the value of 0.249 and this means that the independent variables contributes to the extent of $24.9 \%$ to motivation and it is significant at $1 \%$ level.
\end{abstract}

\title{
INTRODUCTION
}

Education has increasingly become important to success of both individuals and nations. Growing evidence demonstrates that, among all educational resources, teachers' abilities are especially critical contributors to students' learning and consequently the success of a nation to advance in its economic, social and political spheres (Darling-Hammond, 2006).

The focus of teacher preparation had to shift from training to education if it had to make a positive influence on the quality of education transaction in classrooms and thereby pupil learning and the larger social transformation. The aspects that need greater emphasis are;

$>$ the length of academic preparation,

$>$ the level and quality of subject matter knowledge,

$>$ the repertoire of pedagogical skills that teachers possess to meet the needs of diverse learning situations,

$>$ the degree of commitment to the profession,

$>$ sensitivity to contemporary issues and problems and

$>$ the level of motivation.

This is not possible if teacher preparation focused only on training. Holistic teacher building is necessary and therefore teacher education needed more emphasis than mere training by high positive motivation of the student teachers for choosing the teaching as their calling.

\section{TEACHING AS CALLING}

A calling is defined as a strong motivation in which a person repeatedly takes a course of action that is intrinsically satisfying (Buskist, Benson and Sikorski, 2005). When positive psychology tenets are applied to teaching, the instructors behave as if they had callings in that they demonstrate a profound and strong love for teaching. For example, Professor Brewer depicts his teaching as "delightful, invigorating, mysterious, frustrating, passionate, precious and sacred." Professor Brewer (2002) even 
admits that "teaching is more fun than most people should have. David Worley (2001) portrays his teaching as "a dream come true" that he is allowed "to live every day". Moreover, Worley tells his students, "I went back to graduate school and did the difficult and challenging work required for one reason: I wanted to be here with you today." For all these master teachers, their calling represents a perceived privilege: the chance to make a positive difference in the lives of students (Baskit et al., 2005). Thus, student and teacher together undertake an amazing journey in this teaching profession.

\section{CONCEPTUAL AND THEORETICAL PERSPECTIVE - MOTIVATION}

Teaching motivations can be mapped to the main constructs in the Expectancy-Value Motivational Theory (Eccles, 2005; Eccles (Parsons) et al., 1983: Wigfield \& Eccles, 2000) on which the Factors Influencing Teaching (FIT) -Choice scale is founded, an integrative and comprehensive motivational framework to provide a theoretically grounded basis to approach the question of teaching as a career choice. The FIT-Choice model taps both the "altruistic"-type motivations that have been emphasized in the teacher education literature (Book and Freeman, 1986; Brown, 1992; Lortie, 1975; Moran, Kilpatrick. Abbott, Dallatt, and McClune, 2001; Serow and Forrest, 1994), as well as more personally utilitarian motivations, intrinsic motivations, and ability-related beliefs, It also taps individuals' perceptions about the demand and reward aspects of the teaching profession, and contains a measure of career satisfaction and commitment.

Watt and Richardson, 2007, 2008 discuss on how the FIT-Choice factors, summarized, map onto expectancy-value theory, Social Cognitive Career Theory (SCCT; Lent, Lopez, \& Bieschke, 1993) which also highlights the importance of ability-related beliefs, and to key findings within the existing teacher education literature. Success expectancies depend on beliefs about how much ability one possesses, defined by Eccles et al. as beliefs about how well one will perform on an impending task; expectations for success are shaped over time by the individual's experiences and her or his interpretations of them (Eccles \& Wigfield, 1995).

The major identified teaching motives within the teacher education literature - intrinsic, extrinsic and altruistic (Brookhart \& Freeman, 1992) - fit within the expectancy - value component, further differentiated into more nuanced intrinsic, utility, attainment and cost values. The Eccles et al. expectancy-value model (1983) thereby provides a comprehensive framework into which previously identified motives can readily be incorporated, while also suggesting it to others. The sequencing of the FIT- Choice model consists of antecedent socialization influences, followed by more proximal influences of task perceptions, self perceptions, values, and fallback career.

\section{PURPOSE OF THE STUDY}

Quality has become a defining element of education in the 21 st century in the context of new social realities. Quality makes education as much socially relevant as it is personally indispensible to the individuals. In this sense quality becomes the defining element of education. In this context, quality and excellence should be the vision of every higher education institution including teacher education. Acquisition of quality and excellence is the great challenge faced by all higher education institutions.

Various researches throughout the World indicate that an enjoyment of working with children seems to be an important reason for becoming a teacher (Holm 1975; Holm 1989). Student teachers also regard the teaching profession as a worthwhile and challenging profession (Bergem 1994). Jarvis and Woodrow (2005) have found that student motivation is career-related. A challenging, stable and rewarding career and a wish to continue working with the specific subject matter are the most preferred 
reasons for choosing teaching profession. Existing data support the view that the characteristics, experiences, knowledge, dispositions, beliefs, attitudes and perceptions that pre-service teachers bring with them upon entering into a teacher education programme substantially influence their subsequent development as students and eventually, as teachers (Carter, 1990; Minor et al., 2002; Witherell and Noddings, 1991).

It is obvious that quality of teaching force is not governed only by the qualification, pedagogical knowledge and teaching skill of teachers, but also their enthusiasm, motivation, dedication and commitment in teaching. Student teachers have a substantial impact on the education of future generations. In order for a system of teacher education to be effective, it needs to recognize and build on the characteristics and motivations that student teachers bring with them when they enter teacher education program after their completion of graduation or post graduation.

The views of student teachers are frequently overlooked in research on education, but their attitudes towards school, attitudes towards their professional development, moral character involvement, altruistic feel, balancing both negative and positive emotion; and personal and social influence that are more specifically important because of the relationship between their views as student teachers and their later practice in the teacher education program make an impact of teaching profession and the quality that student teachers receive as future teachers are well motivated in teaching.

\section{AN OPERATIONAL DEFINITION}

Motivation - As something which prompts, compels and energizes an individual to act or behaves in a particular manner at a particular time for attaining some specific goal or purpose.

Personal and Social influence - As personal influence which can be either external or internal. External personal influence involves social interaction between two or more people, such as a neighbour, a mother, a father, and a child. Internal personal influence occurs when decisions are influenced by mental processes that have to do with other people or groups. Social influence may focus on ways in which behaviour is influenced by outside factors and thus could be behaviour of a whole group or of discrete individuals.

Emotion - As that one must be competent at understanding his/her emotions..... both positive and negative, be able to process emotional information accurately and efficiently and have the insight to skillfully use one's emotions to solve problems, make plans and achieve their goal in one's life. Hence a person may be said to be emotionally matured if he/she has in choosing the profession almost all types of emotions (positive or negative) the influence and is able to express them at the appropriate time in an appropriate degree to achieve the goal or not.

Altruism - As true altruism- acting with the goal of benefiting others. Altruism influences and acts as a motivational force to increase another's welfare without conscious regard for one's self-interest.

Moral Value - As a relating to human behaviour, especially the distinction between good and bad or right and wrong behaviour; moral sense and moral courage, adhering to conventionally accepted standards of conduct, having psychological rather than tangible effects moral support, having the effects but not the appearance of victory. 
Attitude - As the core of human individuality, the permanent organization of an individual's motivational, emotional, perceptional and mental process towards an event or a psychological object, positive or negative sensual intensity and learned tendency.

\section{RESEARCH QUESTIONS}

1. Is there is any significant difference between male and female student teacher's in all the selected variables?

2. Is there is any significant relationship among the predictor variables and criterion variable?

3. Is there is relative contribution of the predictor variables towards motivation of B.Ed Student teacher's?

\section{METHODOLOGY}

The data for the present study were collected from a population of student teachers. In the present study, Survey Method is employed to describe and interpret. The population of the present study is B.Ed., college student teachers belonging to Pudukkottai District of Tamil Nadu, India. In B.Ed., course both male and female student teachers were chosen. The sample size chosen for B.Ed., student teachers are 500 (250 Male and 250 Female) out of 1386 as the total sample size on 2012 of the Pudukkottai District. Nearly $37 \%$ of the total sample was utilized for the main study.

\section{QUESTION - 1}

Mean difference between male and female student teacher's in all the selected variables $\{\mathbf{N}(500)=$ Male - 250; Female - 250 $\}$

\begin{tabular}{|c|c|c|c|c|c|c|}
\hline Variables & Gender & Mean & SD & $\begin{array}{l}\mathbf{t} \\
\text { value }\end{array}$ & $P$ value & $\begin{array}{l}\text { Level of } \\
\text { Significance }\end{array}$ \\
\hline \multirow[t]{2}{*}{ Motivation } & Male & 67.27 & 10.61 & \multirow[t]{2}{*}{3.065} & \multirow[t]{2}{*}{$0.002 * *$} & \multirow[b]{2}{*}{$\mathbf{S}$} \\
\hline & Female & 70.29 & 11.38 & & & \\
\hline \multirow{2}{*}{$\begin{array}{l}\text { Positive and Negative } \\
\text { Emotion }\end{array}$} & Male & 77.98 & 8.63 & \multirow[t]{2}{*}{3.809} & \multirow[t]{2}{*}{$0.001 * *$} & \multirow[b]{2}{*}{$\mathbf{S}$} \\
\hline & Female & 80.84 & 8.15 & & & \\
\hline \multirow[t]{2}{*}{ Altruism } & Male & 77.64 & 8.14 & \multirow[t]{2}{*}{3.789} & \multirow[t]{2}{*}{$0.001 * *$} & \multirow{2}{*}{$\mathbf{S}$} \\
\hline & Female & 80.24 & 7.17 & & & \\
\hline \multirow[t]{2}{*}{ Moral Value } & Male & 83.90 & 9.39 & \multirow[t]{2}{*}{2.568} & \multirow[t]{2}{*}{$0.011^{*}$} & \multirow{2}{*}{$\mathbf{S}$} \\
\hline & Female & 85.98 & 8.75 & & & \\
\hline \multirow[t]{2}{*}{ Teacher's Attitude } & Male & 73.14 & 9.12 & \multirow[t]{2}{*}{2.866} & \multirow[t]{2}{*}{$0.004 * *$} & \multirow{2}{*}{$\mathbf{S}$} \\
\hline & Female & 75.43 & 8.73 & & & \\
\hline \multirow{2}{*}{$\begin{array}{lll}\text { Personal and } & \text { Social } \\
\text { Influence } & & \end{array}$} & Male & 71.36 & 9.40 & \multirow[t]{2}{*}{4.851} & \multirow[t]{2}{*}{$0.001^{* *}$} & \multirow{2}{*}{$\mathbf{S}$} \\
\hline & Female & 75.35 & 8.99 & & & \\
\hline
\end{tabular}

S - Significant; * - significant at 0.05 level, ** - significant at 0.01 level 
It could be inferred from the table that on the variables of motivation, positive and negative emotion, altruism, teacher's attitude and personal and social influence that there exists significant difference between male and female student teachers at 0.01 level. Whereas, the variable moral value is significant at 0.05 level. It is noted that female student teachers has manifested significantly higher level in all the above selected variables when compared to their counter parts.

\section{QUESTION - 2}

Correlation matrix showing Inter Correlation between selected Independent Variables and Motivation for Choosing teaching as Career among Student Teachers

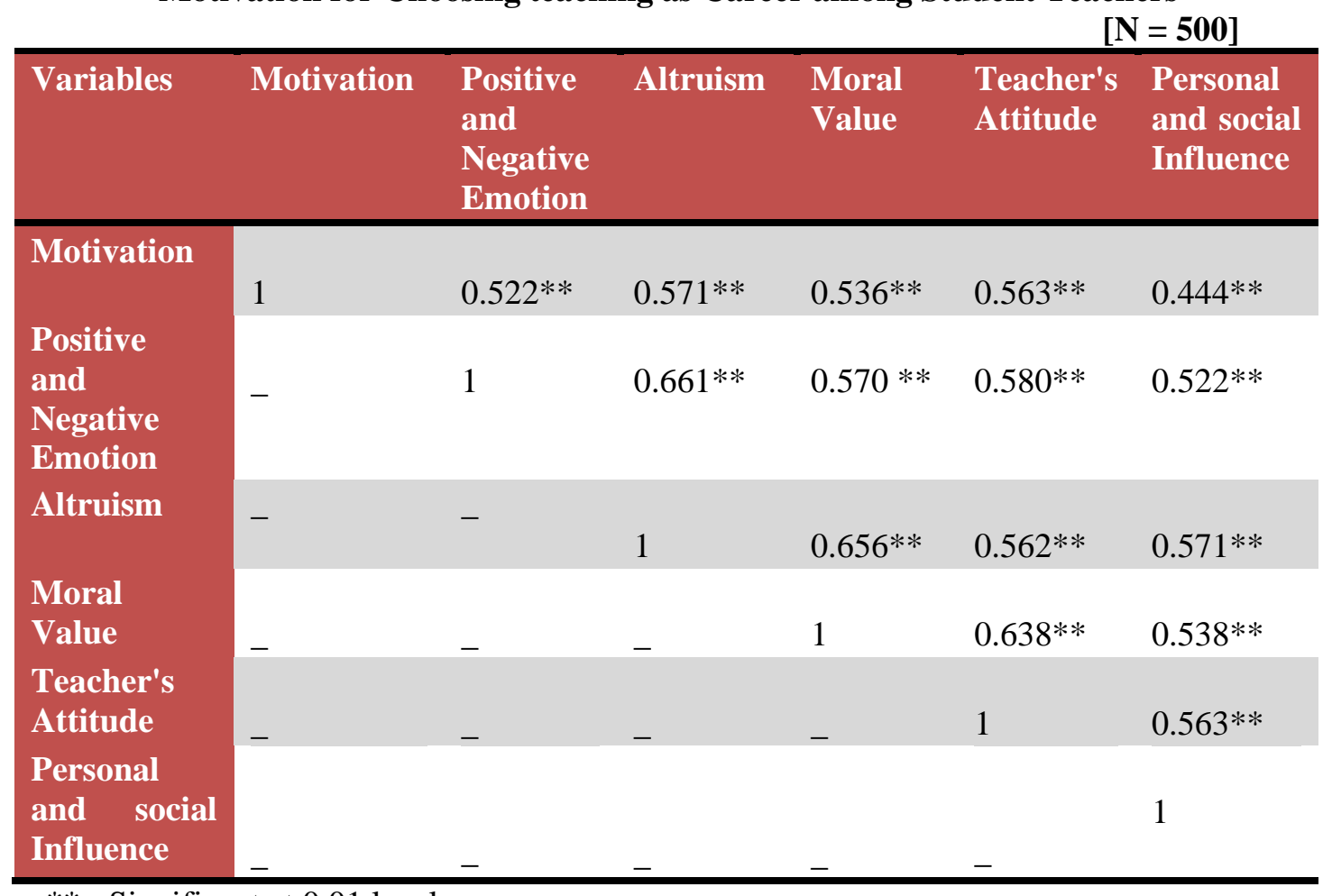

** - Significant at 0.01 level

The inter correlation between the independent variables of the study show significant relation among themselves and also with the dependent variable. The independent variables such as positive and negative emotion, altruism, moral value, teacher's attitude and personal and social influence correlate significantly with motivation positively. Therefore, the results of the student teacher's revealed that higher the positive and negative emotion, altruism, moral value, teacher's attitude and personal and social influence higher the motivation of the student teacher's for choosing teaching as their profession.

\section{QUESTION - 3}

Summary of Multiple Regression Analysis of B.Ed., Student Teacher's

\begin{tabular}{|l|l|l|l|l|l|l|}
\hline Model & R & R Square & $\begin{array}{l}\text { Adjusted R } \\
\text { Square }\end{array}$ & $\begin{array}{l}\text { Std. Error } \\
\text { of } \begin{array}{r}\text { F Value } \\
\text { the }\end{array}\end{array}$ & P value \\
\hline $\mathbf{1}$ & 0.499 & 0.249 & 0.241 & 9.66381 & 32.731 & $0.001^{* *}$ \\
\hline
\end{tabular}

Note: ** Correlation is significant at 0.01 level. 
The multiple correlation coefficient is 0.499 measures the degree of relationship between the actual values and predicted values of student teacher's motivation since the predicted values are obtained as a linear combination of all independent variables.. The value 0.499 indicates that the relationship between motivation and independent variables are quite strong and positive.

The coefficient of determination $\mathrm{R}$ square measures the goodness-of-fit. The value of $\mathrm{R}$ square is 0.249 and this means that the variables such as positive and negative emotion, altruism, moral value, teacher's attitude and personal and social influence contributes to the extent of $24.9 \%$ to motivation and it is significant at $1 \%$ level.

\section{Table 4}

Regression of all Independent Variables for Entire Sample

\begin{tabular}{|l|l|l|l|l|l|}
\hline Variables & \multicolumn{2}{|l|}{$\begin{array}{l}\text { Un standardized } \\
\text { Coefficients }\end{array}$} & $\begin{array}{l}\text { Standardized } \\
\text { Coefficient }\end{array}$ & t value & P value \\
\cline { 2 - 5 } & B & $\begin{array}{l}\text { Std. } \\
\text { Error }\end{array}$ & Beta & & \\
\hline Constant & 22.749 & 4.851 & & 4.690 & $0.001^{* *}$ \\
\hline Positive and negative Emotion & 0.214 & 0.073 & 0.164 & 2.941 & $0.003^{* *}$ \\
\hline Altruism & 0.074 & 0.086 & 0.052 & 0.865 & 0.387 \\
\hline Moral Value & 0.144 & 0.071 & 0.119 & 2.044 & $0.042^{*}$ \\
\hline Teacher's Attitude & -0.346 & 0.069 & 0.281 & -5.023 & $0.001^{* *}$ \\
\hline Personal and Social Influence & 0.500 & 0.061 & 0.424 & 8.208 & $0.001^{* *}$ \\
\hline
\end{tabular}

* - significant at 0.05 level, ** - significant at 0.01 level

The Regression equation can be formulated as follows:

$\mathrm{Y}=0.164 \mathrm{X}_{1}+0.119 \mathrm{X}_{3}+0.281 \mathrm{X}_{4}+0.424 \mathrm{X}_{5}$--- Standard score form

Using this standardized regression equation, the individual contribution of each variable $\mathrm{X}_{1}, \mathrm{X}_{2}$, $\mathrm{X}_{3}, \mathrm{X}_{4}, \mathrm{X}_{5}$ towards the motivation $(\mathrm{Y})$ of the entire sample can be found out.

From table-4, it is inferred that the Beta coefficient of positive and negative emotion (0.164), moral value (0.119), teacher's attitude (0.281) and personal and social influence $(0.424)$. The estimated positive sign implies that the effect of positive and negative emotion, moral value, teacher's attitude and personal and social influence on motivation is positive. Thus, the motivation score would increase by 0.164 for every unit increase in positive and negative emotion, 0.119 for every unit increase in moral value, 0.281 for every unit increase in teacher's attitude, and 0.424 for every unit increase in personal and social influence.

It shall be interpreted from the Beta coefficient that the most important predictor for motivation in the case of entire sample is personal and social influence followed teacher's attitude, positive and negative emotion and moral value. The coefficient value of positive and negative emotion, teacher's attitude and personal and social influence The coefficient value of moral value are significant at $5 \%$ level.

Going through the Beta coefficient, it is found that personal and social influence played a highest and most significant role on motivation of student teacher's where as teacher's attitude, positive and negative emotion and moral value played the least significant role in this entire sample. The coefficient of determination $\mathrm{R}$ square is 0.249 and this simply means that the variables such as positive and negative emotion, moral value, teacher's attitude and personal and social influence to the extent of $24.9 \%$ to the motivation of student teacher's in choosing teaching as their profession. 


\section{RECOMMENDATION}

The findings of the present investigation revealed that student teachers who displayed a positive influence towards teaching, 'love for students and love for teaching' plays a crucial role in counteracting the adverse influence of personal and social factors. This has implications for school and teacher education administrators, who are able to make room and provide support for the seeds of 'love for teaching and students' to blossom and strengthen, especially among future student teachers. The findings of this study show that 'love for teaching' as a personal value and virtue involves student teachers.' It is suggested/recommended that teacher educators could model the development of teacher-pupil relationship, which may in turn have an impact on future teachers learning with their own students. The more asset of love for teaching being accumulated, the better opportunities these student teachers will be able to survive unpredictable challenges ahead with a positive outlook and sustained teaching as a career.

The results regarding gender in the present study raise a raft of issues pertaining to females choosing teaching profession. It is resulted that female student teachers are motivated/influenced more rather than male student teachers. It may be more appropriate for male student teachers to word the professional relational end of attitude towards choosing teaching as their profession by stimulating them during their school education itself. Motivation towards teaching involves building professional relationships with children as most important for all teachers and something with which both male and female student teachers should be concerned and for which both should be rewarded. Hence, it is strongly recommended that teaching is to be an attractive profession for dedicated men and women who wish to be acknowledged as professional teachers in future.

The student teachers are able to sustain and put into a practice a set of altruistic and moral values like helping attitude, gratitude, forgiveness, honesty, care, courage, wisdom and freedom which represent aspiration for a passion for high quality teaching and learning. There should be use of socio-drama, others' rating etc., should be promoted to judge the moral and altruistic value of teaching profession and teachers.

The fact that slightly more than half of the surveyed student teachers indicated their motive factor for choosing teaching as their profession is that they were influenced by personal and social influences. It is important for the government and the teacher education institutions to provide adequate support and allow ample student contact time with teachers so that they can focus their efforts in providing better care and inspiration for student teachers.

\section{CONCLUSION}

The present student teacher populations who are the architects of future citizens are quality future teachers for producing quality students/educational system through their positive motive towards choosing teaching as their career. For those who continuously must make this choice to teach the ability to get closer to one's vision and make a sense of making a difference with student teachers may provide the kind of internal motivation support that future teachers need, which can in some ways counteract the other attractive options that may arise.

\section{Acknowledgement}

I would like to thank my supervisor Dr. N. Kalai Arasi, Associate Professor of Computer Science

Education, N.K.T. National College of Education for Women, Triplicane, Chennai: for motivating throughout my Ph.D., course in completing my research work successfully. 


\section{References}

1. Book, C. L., \& Freeman, D. J. (1986). Differences in entry characteristics of elementary and secondary teacher candidates. Journal of Teacher Education, 37(2), 47-51.

2. Book, C., Freeman, D., \& Brousseau, B. (1985). Comparing academic backgrounds and career aspirations of education and non-education majors. Journals of Teacher Education, 36, 27-30.

3. Brown, M. M. (1992). Caribbean first-year teachers' reasons for choosing teaching as a career. Journal of Education for Teaching, 18(2), 185-195.

4. Eccles (Parsons), J., Adler, T. F., Futterman, R., Goff, S. B., Kaczala, C. M., Meece J. L.(1983). Expectancies, values and academic behaviours. In J. T. Spence (Ed.), Achievement and achievement motivation (pp. 75-146). San Francisco, CA:W.H Freeman.

5. Eccles, J. S. (2005). Studying gender and ethnic differences in participation in math, physical science, and information technology. New Directions in Child and Adolescent Development, 110(Winter), 7-14.

6. Eccles, J. S., \& Wigfield, A. (1995). In the mind of the actor: the structure of adolescents' achievement task values and expectancy-related beliefs. Personality and Social Psychology Bulletin, 21, 215-225.

7. Lent, R. W., Lopez, F. G., \& Bieschke, K. J. (1993). Predicting mathematics-related choice and success behaviors: test of an expanded social cognitive model. Journal of Vocational Behavior, 42, 223-236.

8. Lortie, D. (1975). School-teacher: A sociological study: University of Chicago Press.

9. Moran, A., Kilpatrick, R., Abbott, L., Dallatt, J., \& McClune, B. (2001). Training to teach: motivating factors and implications for recruitment. Evaluation and Research in Education, 15(1), 17-32.

10. Serow, R. C., \& Forrest, K. D. (1994). Motives and circumstances: occupational change experiences of prospective late-entry teachers. Journal of Teaching and Teacher Education, 10(5), 555-563.

11. Serow, R. C., Eaker, D. J., \& Forrest, K. D. (1994). "I want to see some kind of growth out of them": What the service ethic means to teacher-education students. American Educational Research Journal, 31(1), 27-48. 